\title{
The Complete Mitochondrial Genome of Rhacophorus dennysi (Anura: Rhacophoridae) with Novel Gene Arrangements and its Phylogenetic Implications
}

\author{
Yongmin Li ${ }^{1,2}$, Huabin Zhang ${ }^{1}$, Xiaoyou $\mathrm{Wu}^{1}$, Dongwei $\mathrm{Li}^{2}$, Peng $\operatorname{Yan}^{1}$ and \\ Xiaobing $\mathrm{Wu}^{1 *}$ \\ ${ }^{1}$ Anhui Province Key Laboratory for Conservation and Exploitation of Biological \\ Resource, College of Life Sciences, Anhui Normal University, Wuhu, Anhui, China \\ ${ }^{2}$ College of Biology and Food Engineering, Fuyang Normal University, Fuyang, \\ Anhui, China
}

\begin{abstract}
A B S T R A C T
We determined the complete mitochondrial ( $\mathrm{mt}$ ) genome of Rhacophorus dennysi (family Rhacophoridae). The $R$. dennysi mitogenome (18,052 bp) contained the 37 genes and a single control region (CR) typically found in neobatrachian mtDNAs. In the new mt genome, the ND5 gene and a TLPF tRNA cluster (tRNA ${ }^{\text {Thr }}$, tRNA $^{\text {Leu(CUN) }}$, tRNA ${ }^{\text {Pro }}$ and tRNA ${ }^{\text {Phe }}$ ) were located between the CR and the 12S rRNA gene. $R$. dennysi mitochondrial gene rearrangements observed here could be explained by the Tandem Duplication and Random Loss (TDRL) model. We used twelve mitochondrial protein-coding genes of the newly sequenced and other reported species to assess phylogenetic relationships of Ranoidea. Phylogenetic analyses using maximum likelihood (ML) and Bayesian inference (BI) methods supported the sister-group relationship between ((Rhacophoridae + Mantellidae) + Ranidae) and Dicroglossidae. Within Rhacophoridae, two species of the genus Rhacophorus ( $R$. schlegelii and $R$. dennysi) were clustered together with the representative of the genus Polypedates (P. megacephalus), meanwhile, the representative of the genus Buergeria (B. buergeri) occupied the basal position in the clade of Rhacophoridae.
\end{abstract}

\begin{tabular}{l} 
Article Information \\
Received 01 September 2019 \\
Revised 01 May 2020 \\
Accepted 19 June 2020 \\
Available online 25 August 2021 \\
Authors' Contribution \\
\hline XBW designed the study. XYW and \\
YML performed fieldwork. XYW, \\
YML, PY and HBZ analysed the data. \\
YML, XYW, HBZ and DWL wrote \\
the article. \\
Key words \\
\hline Rhacophorus dennysi, Mitochondrial \\
genome, Phlyogenetic relationship, \\
Rhacophoridae
\end{tabular}

\section{INTRODUCTION}

$\mathrm{V}$ ertebrate mitochondrial (mt) DNAs form closed circular molecules which have lengths varying from 15 to $21 \mathrm{~Kb}$ (Boore, 1999; Sano et al., 2005; Chen et al., 2011; Zhang et al., 2015). These mt genomes typically contain 13 protein-coding genes (PCGs), 2 ribosomal RNA (rRNA) genes, and 22 transfer RNA (tRNA) genes and a control region (CR) (Boore, 1999). The CR is a long non-coding region (approximately $0.5 \mathrm{~Kb}-9 \mathrm{~Kb}$ ) (Kurabayashi et al., 2008), which includes signals for regulating and initiating mitochondrial genome replication and transcription and a short non-coding sequence referred to as the light-strand replication origin (OL) (Boore, 1999).

Mitochondrial genes organization is usually conserved in nearly all vertebrates (Boore, 1999). However, the mt gene arrangements of the neobatrachians are different, and a variety of reorganizations have occurred (Kurabayashi and Sumida, 2013; Zhang et al., 2013, 2018;

\footnotetext{
Corresponding author: wuxb@mail.ahnu.edu.cn 0030-9923/2021/0006-2013 \$ 9.00/0

Copyright 2021 Zoological Society of Pakistan
}

Li et al., 2014; Yuan et al., 2016). For instance, there is a lack of the tRNA ${ }^{\text {His }}$ gene in the Odorrana schmackeri mitogenome (Li et al., 2014); a tandem duplication of tRNA $^{\text {Met }}$ gene has been found in the mtDNA of Quasipaa boulengeri (Yuan et al., 2016); ND5 gene between tRNA $^{\text {Ser }}$ and ND6 has been translocated to the region between the CR and the LTPF tRNA cluster in Buergeria buergeri (Sano et al., 2004). The phenomena of $\mathrm{mt}$ gene reorganizations have generally been interpreted by the Tandem Duplication and Random Loss model (San Mauro et al., 2006).

In the Neobatrachia, the phylogenetic relationships among Rhacophoridae, Mantellidae, Dicroglossidae and Ranidae remain controversial. Some phylogenetic studies supported the relationship of ((Rhacophoridae + Mantellidae $)+$ (Dicroglossidae + Ranidae $)$ )

\footnotetext{
Abbreviations

PCR, polymerase chain reaction; rRNA, Ribosomal RNA; tRNA, transfer RNA; ATP6, ATPase subunit 6; ATP8, ATPase subunit 8; bp, base pairs; COI-III, cytochrome c oxidase subunit I-III; Cyt b, cytochrome b; CR, control region; $\mathrm{H}$ strand, heavy strand; L strand, light strand; mtDNA, mitochondrial DNA; ND1-6, and ND4L, NADH dehydrogenase subunit 1-6, and 4L; OL, L-strand replication; ML, maximum likelihood; BI, Bayesian inference.
} 
(Zhang et al., 2009, 2018; Chen et al., 2011), but others supported a sister-taxon relationship between ((Rhacophoridae+Mantellidae) + Ranidae) and Dicroglossidae (Frost et al., 2006; Pyron and Wiens, 2011; Kakehashi et al., 2013; Kurabayashi and Sumida, 2013; Kurabayashi et al., 2010; Zhang et al., 2013; Li et al., 2014; Xia et al., 2014; Yuan et al., 2016; Chen et al., 2017).

mtDNA is an important molecular marker and has been widely used in the studies of genetics, phylogenetics and phylogeography. In the present study, we determined the complete nucleotide sequence of the mitochondrial genome of Rhacophorus dennysi. We performed phylogenetic analyses based on complete $\mathrm{mt}$ genomes of the newly sequenced and other reported species of Ranoidea to assess the taxonomic position of Rhacophorus dennysi, and to test the phylogenetic relationship of Rhacophoridae and Ranidae.

\section{MATERIALS AND METHODS}

\section{Sample collection and PCR}

The $R$. dennysi sample was collected from Qifeng, Guniujiang, Anhui province in China. This frog sample used was stored at $-40^{\circ} \mathrm{C}$ (Sample No. AM12026) in the Conservation Biology Laboratory, College of Life Sciences of Anhui Normal University. Total DNA was extracted from a piece of muscle tissue by proteinase $\mathrm{K}$ digestion, phenol-chloroform extraction, and ethanol precipitation (Sambrook et al., 2001).

To determine the complete mitochondrial genomic sequence of $R$. dennysi, polymerase chain reaction (PCR) was carried out with the primers for the mtDNAs of frogs described in the literatures (Kurabayashi and Sumida, 2009; Zhang et al., 2013). Furthermore, based on the complete mtDNA sequences of $R$. schlegelii (AB202078) and $P$. megacephalus (AY458598), we also designed two pairs of primers to amplify $\mathrm{mt}$ fragments from the $C y t b$ gene to the ND5 gene. PCR reaction volume of $30 \mu$ contained $21 \mu 1$ sterile double distilled water, $3 \mu 110 \times$ reaction buffer (with $\mathrm{Mg}^{2+}$ ), $2.5 \mu \mathrm{l}(2.5 \mathrm{mmol} / \mathrm{l}) \mathrm{dNTPs}, 1 \mu \mathrm{l}$ each primer $(10 \mu \mathrm{mol} / 1), 0.5 \mu 1$ Taq DNA polymerase (TaKaRa Bio Inc., Otsu, Shiga, Japan) and $1 \mu 1$ template DNA. Amplification was performed using Applied Biosystems 2720 Thermal Cycler with the following conditions: initial denaturation at $94^{\circ} \mathrm{C}$ for $4 \mathrm{~min}, 32$ cycles of denaturation at $94^{\circ} \mathrm{C}$ for $40 \mathrm{~s}$, annealing at $52-58^{\circ} \mathrm{C}$ for $40 \mathrm{~s}$ and elongation at $72^{\circ} \mathrm{C}$ for $60 \mathrm{~s}$, and a final extension at $72{ }^{\circ} \mathrm{C}$ for $10 \mathrm{~min}$. The resulting PCR fragments were separated by electrophoresis in $1.0 \%$ agarose gels, then PCR products were purified using TIANquick Midi Purification Kit (TIANGEN Bio Inc., Beijing, China), and then directly sequenced on an automated sequencer (ABI 3730) from both strands.

\section{Sequence assembly and analysis}

Nucleotide sequences were checked and assembled using the program SeqMan (DNASTAR Inc., Madison, WI, USA). The 13 protein-coding and two rRNA genes were annotated by comparison with the known complete mtDNA sequences of Rhacophorus schlegelii (Sano et al., 2005), Polypedates megacephalus (Zhang et al., 2005) and Buergeria buergeri (Sano et al., 2004). The 22 tRNA genes were identified by their cloverleaf secondary structure and anticodon sequences using tRNA Scan-SE v.2.0.2 (http://lowelab.ucsc.edu/tRNAscan-SE; Lowe and Chan, 2016). The complete mtDNA sequence of $R$. dennysi was deposited in GenBank with the accession number KM035412.

\section{Phylogenetic reconstruction}

In order to address the phylogenetic relationships among Rhacophoridae, 3 additional, previously published Rhacophoridae mitogenomes were included in the analysis. In addition, mitochondrial genomes from one species in the family Mantellidae, twenty-two species in Ranidae, and thirteen species in Dicroglossidae were retrieved from GenBank to further confirm the phylogenetic position of the family Rhacophoridae among Ranoidea. Additionally, three Microhylidae species were used as the outgroups based on Pyron and Wiens (2011) (Table I).

We constructed the phylogenies using the concatenated $12 \mathrm{mt}$ protein-coding genes and partitioned these genes by codon position. The best fitted substitution model for each partition was estimated using Akaike Information Criterion (AIC) implemented in jModeltest v.2.1.7 (Darriba et al., 2012). The GTR $+\mathrm{I}+\mathrm{G}$ model was chosen for ML and Bayesian inference (BI) analyses, which were separately performed using RaxML (Kozlov et al., 2019) with 1000 bootstrap replications and MrBayes v.3.2.7 (Ronquist et al., 2012). Besides, the following settings were applied in the BI analysis: 10 million Markov chain Monte Carlo (MCMC) generations, a sampling frequency of 1000 , burn-in $=1000$.

\section{RESULTS}

\section{Genome organization of $\mathrm{R}$. dennysi $m t D N A$}

The $R$. dennysi $\mathrm{mt}$ genome was 18,052 bp in length, containing 13 protein-coding genes, 2 rRNA genes, 22 tRNA genes and a control region (Table II). The base composition of the light strand (L-strand) was 31.5.9\% A, $31.0 \% \mathrm{~T}, 23.2 \% \mathrm{C}$, and $14.3 \% \mathrm{G}$, which is similar to other vertebrates (Zhang et al., 2015; Li et al., 2016). 
Table I. Species in phylogenetic analyses.

\begin{tabular}{|c|c|c|}
\hline Family & Species & $\begin{array}{l}\text { GenBank } \\
\text { accession no. }\end{array}$ \\
\hline \multirow{3}{*}{ Microhylidae } & Kaloula pulchra & NC_006405 \\
\hline & Microhyla okinavensis & NC_010233 \\
\hline & M. heymonsi & NC_006406 \\
\hline Mantellidae & Mantella madagascariensis & NC_007888 \\
\hline \multirow[t]{4}{*}{ Rhacophoridae } & Buergeria buergeri & NC_008975 \\
\hline & Polypedates megacephalus & NC_006408 \\
\hline & Rhacophorus schlegelii & NC_007178 \\
\hline & R. dennysi & KM035412 \\
\hline \multirow[t]{22}{*}{ Ranidae } & Pelophylax ridibundus & JN627421 \\
\hline & P. lessonae & JN627426 \\
\hline & P. esculenta & JN627424 \\
\hline & P. chosenica & NC_016059 \\
\hline & P. nigromaculata & NC_002805 \\
\hline & P. plancyi & NC_009264 \\
\hline & Amolops mantzorum & KJ546429 \\
\hline & A. ricketti & KF956111 \\
\hline & A. wuyiensis & KJ933509 \\
\hline & Odorrana schmackeri & KJ149452 \\
\hline & O. tormotus & NC_009423 \\
\hline & O. ishikawae & NC_015305 \\
\hline & Rana catesbeiana & NC_022696 \\
\hline & R. dybowskii & NC_023528 \\
\hline & R. cf. chensinensis & NC_023529 \\
\hline & Babina holsti & NC_022870 \\
\hline & B. subaspera & NC_022871 \\
\hline & B. okinavana & NC_022872 \\
\hline & B. adenopleura & JX033120 \\
\hline & Hylarana albolabris & JX564871 \\
\hline & H._guentheri & KM035413 \\
\hline & Rugosa tientaiensis & KJ941041 \\
\hline \multirow[t]{13}{*}{ Dicroglossidae } & Hoplobatrachus rugulosus & NC_019615 \\
\hline & H. tigerinus & NC_014581 \\
\hline & Euphlyctis hexadactylus & NC_014584 \\
\hline & Fejervarya cancrivora & NC_012647 \\
\hline & F. limnocharis & NC_005055 \\
\hline & Limnonectes bannaensis & NC_012837 \\
\hline & L. fujianensis & NC_007440 \\
\hline & L. fragilis & AY899241 \\
\hline & Quasipaa boulengeri & NC_021937 \\
\hline & Paa spinosa & NC_013270 \\
\hline & Nanorana pleskei & NC_016119 \\
\hline & N. taihangnica & KJ569109 \\
\hline & Occidozyga martensii & NC_014685 \\
\hline
\end{tabular}

Table II. Location of features in the mitochondrial DNA of Rhacophus dennysi.

\begin{tabular}{|c|c|c|c|c|c|c|c|}
\hline \multirow[t]{2}{*}{ Region } & \multicolumn{2}{|c|}{$\begin{array}{l}\text { Nucleotide } \\
\text { No. }\end{array}$} & \multirow[t]{2}{*}{$\begin{array}{l}\text { Size } \\
\text { (bp) }\end{array}$} & \multicolumn{2}{|c|}{ Codon } & \multirow{2}{*}{$\begin{array}{l}\text { Spacer } \\
(+) / \text { Over- } \\
\text { lap (-) }\end{array}$} & \multirow[t]{2}{*}{ strand } \\
\hline & From & To & & Start & $\overline{\text { Stop }}$ & & \\
\hline $\mathrm{CR}$ & 1 & 2603 & 2603 & & & & \\
\hline ND5 & 2604 & 4376 & 1773 & ATG & TAA & & $\mathrm{H}$ \\
\hline $\mathrm{tRNA}^{\mathrm{Thr}}$ & 4472 & 4541 & 70 & & & 95 & $\mathrm{H}$ \\
\hline tRNA ${ }^{\operatorname{Leu}(\mathrm{CUN})}$ & 4556 & 4627 & 72 & & & 14 & $\mathrm{H}$ \\
\hline tRNA $^{\text {Pro }}$ & 4642 & 4704 & 63 & & & 14 & $\mathrm{~L}$ \\
\hline $\mathrm{tRNA}^{\mathrm{Phe}}$ & 4705 & 4774 & 70 & & & & $\mathrm{H}$ \\
\hline 12S rRNA & 4775 & 5702 & 928 & & & & $\mathrm{H}$ \\
\hline $\mathrm{tRNA}^{\mathrm{Val}}$ & 5703 & 5771 & 69 & & & & $\mathrm{H}$ \\
\hline 16S rRNA & 5772 & 7352 & 1581 & & & & $\mathrm{H}$ \\
\hline tRNA ${ }^{\text {Leu(UUR })}$ & 7353 & 7425 & 73 & & & & $\mathrm{H}$ \\
\hline ND1 & 7426 & 8386 & 961 & ATA & T- & & $\mathrm{H}$ \\
\hline $\mathrm{tRNA}^{\mathrm{Ile}}$ & 8387 & 8457 & 71 & & & & $\mathrm{H}$ \\
\hline tRNA ${ }^{\text {Gln }}$ & 8457 & 8527 & 71 & & & -1 & $\mathrm{~L}$ \\
\hline $\mathrm{tRNA}^{\mathrm{Met}(\mathrm{AuN})}$ & 8527 & 8595 & 69 & & & -1 & $\mathrm{H}$ \\
\hline ND2 & 8596 & 9633 & 1038 & ATT & TAG & & $\mathrm{H}$ \\
\hline $\mathrm{tRNA}^{\mathrm{Trp}}$ & 9637 & 9707 & 71 & & & 3 & $\mathrm{H}$ \\
\hline tRNA Ala $^{\text {Ala }}$ & 9708 & 9777 & 70 & & & & $\mathrm{~L}$ \\
\hline tRNA ${ }^{\mathrm{Asn}}$ & 9779 & 9851 & 73 & & & 1 & $\mathrm{~L}$ \\
\hline $\mathrm{OL}$ & 9852 & 9881 & 30 & & & & - \\
\hline tRNA ${ }^{\text {Cys }}$ & 9879 & 9943 & 65 & & & -3 & $\mathrm{~L}$ \\
\hline tRNA $A^{\mathrm{Tyr}}$ & 9944 & 10010 & 67 & & & & $\mathrm{~L}$ \\
\hline $\mathrm{COI}$ & 10015 & 11568 & 1554 & ATA & AGG & 4 & $\mathrm{H}$ \\
\hline $\mathrm{tRNA}^{\mathrm{Ser}(\mathrm{UCN})}$ & 11556 & 11626 & 71 & & & -13 & $\mathrm{~L}$ \\
\hline $\mathrm{tRNA}^{\mathrm{Asp}}$ & 11629 & 11697 & 69 & & & 2 & $\mathrm{H}$ \\
\hline COII & 11698 & 12381 & 684 & ATG & TAA & & $\mathrm{H}$ \\
\hline $\mathrm{tRNA}^{\text {Lys }}$ & 12393 & 12463 & 71 & & & 11 & $\mathrm{H}$ \\
\hline ATP8 & 12464 & 12628 & 165 & ATG & TAA & & $\mathrm{H}$ \\
\hline ATP6 & 12607 & 13300 & 694 & ATG & $\mathrm{T}-$ & -22 & $\mathrm{H}$ \\
\hline COIII & 13301 & 14084 & 784 & ATG & $\mathrm{T}-$ & & $\mathrm{H}$ \\
\hline tRNA ${ }^{\text {Gly }}$ & 14085 & 14152 & 68 & & & & $\mathrm{H}$ \\
\hline ND3 & 14153 & 14492 & 340 & ATG & $\mathrm{T}-$ & & $\mathrm{H}$ \\
\hline tRNA ${ }^{\text {Arg }}$ & 14493 & 14561 & 69 & & & & $\mathrm{H}$ \\
\hline ND4L & 14564 & 14848 & 285 & ATG & TAA & & $\mathrm{H}$ \\
\hline ND4 & 14842 & 16204 & 1363 & ATG & T- & & $\mathrm{H}$ \\
\hline tRNA ${ }^{\text {His }}$ & 16205 & 16273 & 69 & & & & $\mathrm{H}$ \\
\hline tRNA ${ }^{\operatorname{Ser}(A G Y)}$ & 16274 & 16340 & 67 & & & & $\mathrm{H}$ \\
\hline ND6 & 16345 & 16836 & 492 & ATG & TAA & & $\mathrm{L}$ \\
\hline tRNA $A^{\text {Glu }}$ & 16837 & 16904 & 68 & & & & $\mathrm{~L}$ \\
\hline Cyt b & 16907 & 18052 & 1146 & ATG & TAA & & $\mathrm{H}$ \\
\hline
\end{tabular}


Remarkably, the tree frog $R$. dennysi possessed a novel mitogenomic gene organization much different from other neobatrachians. In the $R$. dennysi mt genome, the ND5 gene between tRNA ${ }^{\text {Ser }}$ (AGY) and ND6 was translocated to a position between the CR and tRNA ${ }^{\mathrm{Thr}}$. In this new mitogenome, four tRNA genes (tRNA ${ }^{\mathrm{Thr}}$, tRNA $^{\mathrm{Leu}(\mathrm{CUN})}$, tRNA ${ }^{\text {Pro }}$ and $\mathrm{tRNA}^{\text {Phe }}$ ) Formed a $T L P F$ tRNA cluster, different from the neobatrachian-type arrangement (Sumida et al., 2001; Irisarri et al., 2012; Li et al., 2014).

Among the 13 protein-encoding genes in the $R$. dennysi mitogenome, most of these protein-coding genes started with the common initiation codon ATG except two genes (NDI and COI) beginning with ATA, one gene (ND2) beginning with ATT. Stop codons were variable for all protein-coding genes. Seven protein genes (ND2, COII, ATP8, ND4L, ND5, ND6 and Cytb) used complete stop codon TAR, and $C O I$ ended with AGG, whereas other genes (ND1, ATP6, COIII, ND3 and ND4) ended with incomplete stop codon $\mathrm{T}$.

The noncoding regions in the $R$. dennysi mtDNA contained the control region and some spacers. The control region was located between the $C y t b$ and ND5 genes with the length of 2,603 bp. The length of the CR in this study is obviously longer than that of $R$. Dennysi $(2,122 \mathrm{bp})$ in the literature of Huang et al. (2016).

\section{Phylogenetic analyses}

The BI and ML analyses of the molecular dataset produced the identical topologies and very similar branch support (Fig. 1). In the phylogeny of Rhacophoridae, Ranidae, Dicroglossidae and Mantellidae, the monophyly of Dicroglossidae, Ranidae and Rhacophoridae are well supported.

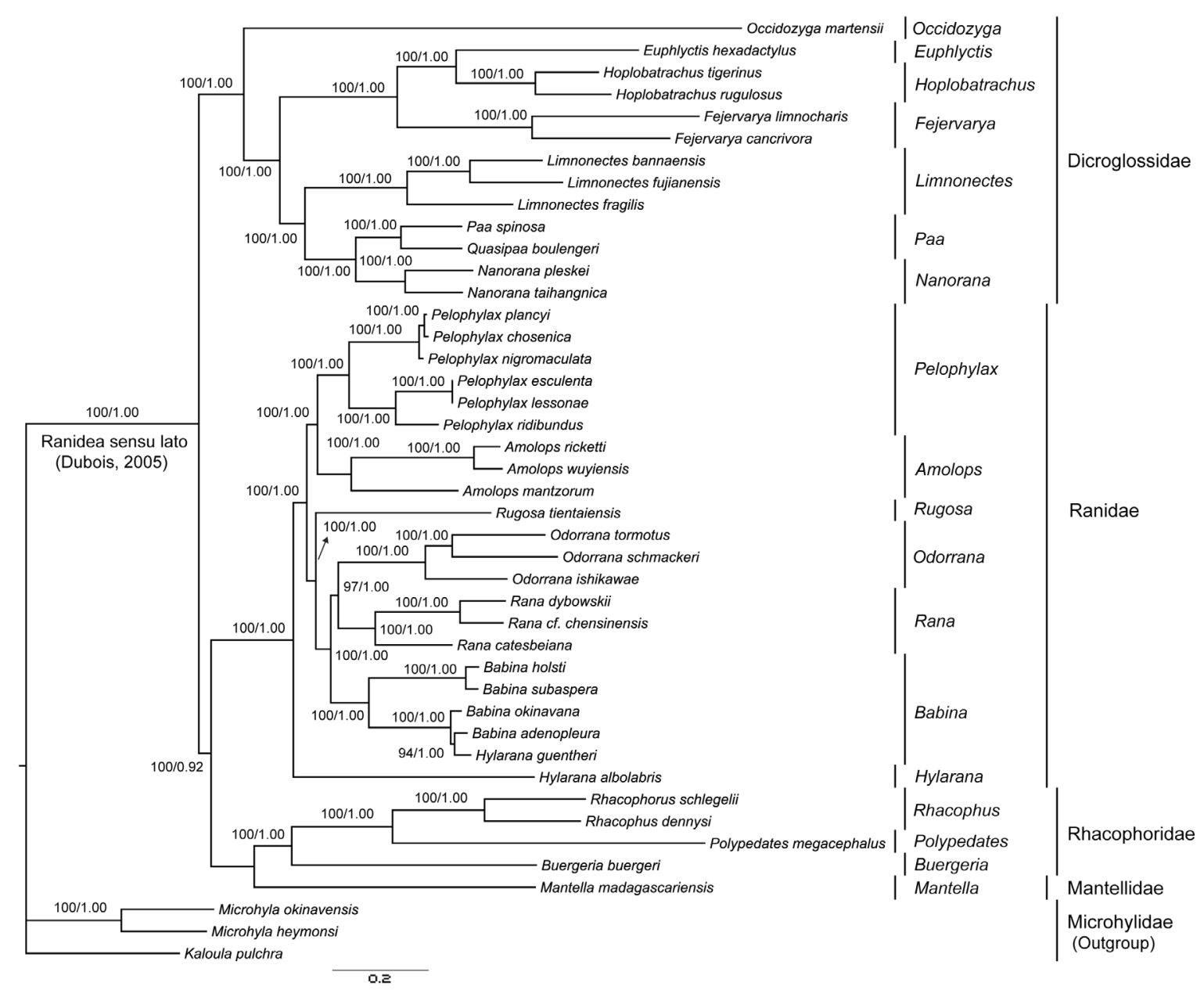

Fig. 1. The phylogeny of Ranidae sensu lato (Dubois, 2005) inferred from the combined sequences of 12 protein-coding and two rRNA genes. The Bayesian tree was shown here, the ML had an identical tree topology. Numbers of nodes were support values from ML (bootstrap proportions; left) and BI (posterior probabilities; right). 
In our tree, the 40 in group species referred in this study were divided into four major clades: Mantellidae, Rhacophoridae, Ranidae and Dicroglossidae, which strongly supported the monophyly of Dicroglossidae, Ranidae and Rhacophoridae. Rhacophoridae was a sister clade to Mantellidae with strong supports $(\mathrm{BP}=100, \mathrm{PP}$ $=1.00)$ and the clade of (Rhacophoridae + Mantellidae) appeared as the sister taxon to Ranidae $(\mathrm{BP}=100, \mathrm{PP}=$ $0.92)$, then together as a sister group of the Dicroglossidae $(\mathrm{BP}=100, \mathrm{PP}=1.00)$. The Rhacophoridae clade included 4 species $R$. schlegelii, $R$. dennysi, P. megacephalus, $B$. buergeri. $R$. schlegelii and $R$. dennysi were grouped as the sister clade of $P$. megacephalus with high supports (BP $=100, \mathrm{PP}=1.00)$, then together as a sister taxon of $B$. buergeri $(\mathrm{BP}=100, \mathrm{PP}=1.00)$.

\section{DISCUSSION}

Gene rearrangement and the significance for the phylogeny

In present study, we discovered a novel gene arrangement of $R$. dennysi $\mathrm{mt}$ genome. The ND5 gene and four tRNA genes (tRNA ${ }^{\mathrm{Thr}}$, tRNA ${ }^{\mathrm{Leu}(\mathrm{CUN})}, \mathrm{tRNA}^{\text {Pro }}$ and $\mathrm{tRNA}^{\text {Phe }}$ forming TLPF tRNA cluster) were located between the CR and the 12S rRNA gene, which differed from the neobatrachian-type arrangement (LTPF tRNA cluster) but shared similarities to those of $R$. schlegelii (Sano et al., 2005) and P. megacephalus (Zhang et al., 2005), two other species from the same family. Gene rearrangement in animal mtDNA is generally believed to take place through the Tandem Duplication and Random Loss (TDRL) model (San Mauro et al., 2006). According to the TDRL model, a multigene portion of the genome is duplicated, then one copy becomes nonfunctional and is subsequently deleted from the genome.

Generally, gene rearrangements have been considered as useful indicators to resolve some phylogenetic relationships (San Mauro et al., 2006; Zhang et al., 2018). For example, the duplication of tRNA ${ }^{\text {Met }}$ likely appeared in all the descendants of Dicroglossidae, indicating that the duplicated tRNA ${ }^{\text {Met }}$ genes can be regarded as a synapomorphic character of Dicroglossidae (Alam et al., 2010; Chen et al., 2011, 2017).

Within neobatrachians, the translocation of ND5 was discovered in two distinct lineages: Rhacophoroidea and Mantellidae, and a part of Dicroglossidae (Occidozyga, Fejervarya, Euphlyctis and Hoplobatrachus) (Sano et al., 2004, 2005; Kurabayashi et al., 2008; Alam et al., 2010; Chen et al., 2017). Thus, convergent gene rearrangements occur frequently in non-sister lineages (Kurabayashi and Sumida, 2013). We should require careful consideration when genomic features are employed for phylogenetic relationship.

\section{Phylogeny of Ranoidea (Dubois 2005)}

Phylogeny of Ranoidea (i.e., Rhacophoridae, Mantellidae, Ranidae and Dicroglossidae) has not reached a consensus (Chen et al., 2011; Yuan et al., 2016). In our analyses, the sister-group relationship between ((Rhacophoridae + Mantellidae) + Ranidae) and Dicroglossidae has been well supported $(\mathrm{BP}=100, \mathrm{PP}=$ 1.00), consistent with the molecular studies of Kakehashi et al. (2013), Kurabayashi and Sumida (2013), Zhang et al. (2013), Xia et al. (2014), Yuan et al. (2016) and Chen et al. (2017).

\section{Phylogenetic analyses of Rhacophoridae}

In our phylogenetic trees, two species of the genus Rhacophorus ( $R$. schlegelii and $R$. dennysi) were clustered together with the representative of the genus Polypedates ( $P$. megacephalus), indicating a very close phylogenetic relationship, meanwhile, the representative of the genus Buergeria (B. buergeri) occupied the basal position in the clade of Rhacophoridae. The phylogenetic relationship among the representatives of the family Rhacophoridae revealed here is congruent with the results of most phylogenetic analyses (Yu et al., 2009; Pyron and Wiens, 2011; Zhang et al., 2013, 2018; Chen et al., 2017; Chan et al., 2018).

\section{CONCLUSIONS}

As a whole, this study provides some evidence for the generic classification of Rhacophoridae proposed by Pyron and Wiens (2011), and our phylogenetic analyses supported the sister-group relationship between ((Rhacophoridae + Mantellidae) + Ranidae) and Dicroglossidae.

\section{ACKNOWLEDGMENTS}

This research was supported by the National Natural Science Foundation of China (31872253), the Provincial Nature Science Research Projects of Anhui Colleges (KJ2018A0331; KJ2018A0350), the GovernmentUniversity Cooperation Projects (XDHX201718; XDHXTD201701; 2017TSJY04) and the Scientific Research Projects of the Inner Mongolian Higher Educational System (NJZY19025).

\section{Statement of conflict of interest}

The authors have declared no conflict of interest.

\section{REFERENCES}

Alam, M.S., Kurabayashi, A., Hayashi, Y., Sano, N., Khan, M.M., Fujii, T. and Sumida, M., 
2010. Complete mitochondrial genomes and novel gene rearrangements in two dicroglossid frogs, Hoplobatrachus tigerinus and Euphlyctis hexadactylus, from Bangladesh. Genes Genet. Syst., 85: 219-232. https://doi.org/10.1266/ggs.85.219

Boore, J.L., 1999. Animal mitochondrial genomes. Nucl. Acids Res., 27: 1767-1780. https://doi.org/10.1093/ nar/27.8.1767

Chan, K.O., Grismer, L.L. and Brown, R.M., 2018. Comprehensive multi-locus phylogeny of old world tree frogs (Anura: Rhacophoridae) reveals taxonomic uncertainties and potential cases of over-and underestimation of species diversity. Mol. Phylogenet. Evol., 127: 1010-1019. https://doi. org/10.1016/j.ympev.2018.07.005

Chen, G., Wang, B., Liu, J., Xie, F. and Jiang, J.P., 2011. Complete mitochondrial genome of Nanorana pleskei (Amphibia: Anura: Dicroglossidae) and evolutionary characteristics of the amphibian mitochondrial genomes. Curr. Zool., 57: 785-805. https://doi.org/10.1093/czoolo/57.6.785

Chen, Z., Li, H., Zhu, Y., Feng, Q., He, Y. and Chen, X., 2017. Molecular phylogeny of the family Dicroglossidae (Amphibia: Anura) inferred from complete mitochondrial genomes. Biochem. Syst. Ecol., 71: 1-9. https://doi.org/10.1016/j. bse.2017.01.006

Darriba, D., Taboada, G.L., Doallo, R. and Posada, D., 2012. J. Model Test 2: more models, new heuristics and parallel computing. Nat. Meth., 9: 772. https:// doi.org/10.1038/nmeth.2109

Dubois, A., 2005. Amphibia Mundi. 1.1. An ergotaxonomy of recent amphibians. Alytes, 23: $1-24$.

Frost, D.R., Grant, T., Faivovich, J., Bazin, R.H., Haas, A., Haddad, C.F.B., de Sá, R.O., Channing, A., Wilkinson, M., Donnellan, S.C., Raxworthy, C.J., Campbell, J.A., Blotto, B.L., Moler, P., Drewes, R.C., Nussbaum, R.A., Lynch, J.D., Green, D.M. and Wheeler, W.C., 2006. The amphibian tree of life. Bull. Am. Mus. Nat. Hist., 33: 1-291. https:// doi.org/10.1206/0003-0090(2006)297[0001:TATO L]2.0.CO;2

Huang, M.Y., Lv, T., Duan, R.Y., Zhang, S.Y. and Li, H.R., 2016. The complete mitochondrial genome of Rhacophorus dennysi (Anura: Rhacophoridae) and phylogenetic analysis. Mitochond. DNA A., 27: 3719-3720. https://doi.org/10.3109/19401736.201 5.1079873

Irisarri, I., San Mauro, D., Abascal, F., Ohler, A., Vences, M. and Zardoya, R., 2012. The origin of modern frogs (Neobatrachia) was accompanied by acceleration in mitochondrial and nuclear substitution rates. BMC Genom., 13: 626. https:// doi.org/10.1186/1471-2164-13-626

Kakehashi, R., Kurabayashi, A., Oumi, S., Katsuren, S., Hoso, M. and Sumida, M. 2013. Mitochondrial genomes of Japanese Babina frogs (Ranidae, Anura): Unique gene arrangements and the phylogenetic position of genus Babina. Genes Genet. Syst., 88: 59-67. https://doi.org/10.1266/ ggs.88.59

Kozlov, A.M., Darriba, D., Flouri, T., Flouri, T., Morel, B. and Stamatakis, A., 2019. RAxML-NG: a fast, scalable and user-friendly tool for maximum likelihood phylogenetic inference. Bioinformatics, 35: 4453-4455. https://doi.org/10.1093/ bioinformatics/btz305

Kurabayashi, A. and Sumida, M., 2009. PCR primers for the neobatrachian mitochondrial genome. Curr. Herpetol., 28: 1-11. https://doi. org/10.3105/018.028.0101

Kurabayashi, A. and Sumida, M., 2013. Afrobatrachian mitochondrial genomes: genome reorganization, gene rearrangement mechanisms, and evolutionary trends of duplicated and rearranged genes. $B M C$ Genom., 14: 633. https://doi.org/10.1186/14712164-14-633

Kurabayashi, A., Sumida, M., Yonekawa, H., Glaw, F., Vences, M. and Hasegawa, M., 2008. Phylogeny, recombination, and mechanisms of stepwise mitochondrial genome reorganization in mantellid frogs from Madagascar. Mol. Biol. Evol., 25: 874891. https://doi.org/10.1093/molbev/msn031

Kurabayashi, A., Yoshikawa, N., Sato, N., Hayashi, Y., Oumi, S., Fujii, T. and Sumida, M., 2010. Complete mitochondrial DNA sequence of the endangered frog Odorrana ishikawae (family Ranidae) and unexpected diversity of $\mathrm{mt}$ gene arrangements in ranids. Mol. Phylogenet. Evol., 56: 543-553. https:// doi.org/10.1016/j.ympev.2010.01.022

Li, Y.M., Wu, X.Y., Zhang, H.B., Yan, P., Xue, H. and $\mathrm{Wu}, \mathrm{X} . \mathrm{B}$, 2016. The complete mitochondrial genome of Amolops ricketti (Amphidia, Anura, Ranidae). Mitochond. DNA A., 27: 242-243. https:// doi.org/10.3109/19401736.2014.883606

Li, Y.M., Zhang, H.B., Wu, X.Y., Xue, H., Yan, P. and $\mathrm{Wu}, \mathrm{X} . \mathrm{B} ., 2014$. A novel mitogenomic rearrangement for Odorrana schmackeri (Anura: Ranidae) and phylogeny of Ranidae inferred from thirteen mitochondrial protein-coding genes. Amphibia-Reptilia, 35: 331-343. https://doi. org/10.1163/15685381-00002958

Lowe, T.M. and Chan, P.P., 2016. tRNAscan-SE On- 
line: integrating search and context for analysis of transfer RNA genes. Nucl. Acids Res., 44: W54-W57. https://doi.org/10.1093/nar/gkw413

Pyron, R.A. and Wiens, J.J., 2011. A large-scale phylogeny of Amphibia including over 2800 species, and a revised classification of extant frogs, salamanders, and caecilians. Mol. Phylogenet. Evol., 61: 543-583. https://doi.org/10.1016/j. ympev.2011.06.012

Ronquist, F., Teslenko, M.D. and Mark, P.V., 2012. MrBayes 3.2: Efficient Bayesian phylogenetic inference and model choice across a large model space. Syst. Biol., 61: 539-542. https://doi. org/10.1093/sysbio/sys029

Sambrook, J., Russell, D.W. and Russell, D.W., 2001. Molecular cloning: a laboratory manual (3-volume set). Cold spring harbor laboratory press, New York.

San Mauro, D., Gower, D.J., Zardoya, R. and Wilkinson, M., 2006. A hotspot of gene order rearrangement by tandem duplication and random loss in the vertebrate mitochondrial genome. Mol. Biol. Evol., 23: 227-234. https://doi.org/10.1093/molbev/ msj025

Sano, N., Kurabayashi, A., Fujii, T., Yonekawa, H. and Sumida, M., 2005. Complete nucleotide sequence of the mitochondrial genome of Schlegel's tree frog Rhacophorus schlegelii (family Rhacophoridae): duplicated control regions and gene rearrangements. Genes Genet. Syst., 80: 213-224. https://doi. org/10.1266/ggs.80.213

Sano, N., Kurabayashi, A., Fujii, T., Yonekawa, H. and Sumida, M., 2004. Complete nucleotide sequence and gene rearrangement of the mitochondrial genome of the bell-ring frog, Buergeria buergeri (family Rhacophoridae). Genes Genet. Syst., 79: 151-163. https://doi.org/10.1266/ggs.79.151

Sumida, M., Kanamori, Y., Kaneda, H., Kato, Y., Nishioka, M., Hasegawa, M. and Yonekawa, H., 2001. Complete nucleotide sequence and gene rearrangement of the mitochondrial genome of the Japanese pond frog Rana nigromaculata. Genes Genet. Syst., 76: 311-325. https://doi.org/10.1266/ ggs.76.311

Xia, Y., Zheng, Y.C., Miura, I., Wong, P.B., Murphy, R.W. and Zeng, X., 2014. The evolution of mitochondrial genomes in modern frogs (Neobatrachia): nonadaptive evolution of mitochondrial genome reorganization. BMC Genom., 15: 691. https://doi. org/10.1186/1471-2164-15-691

Yu, G.H., Rao, D.Q., Zhang, M.W. and Yang, J.X., 2009. Re-examination of the phylogeny of Rhacophoridae (Anura) based on mitochondrial and nuclear DNA. Mol. Phylogenet. Evol., 50: 571-579. https://doi. org/10.1016/j.ympev.2008.11.023

Yuan, S., Xia, Y., Zheng, Y. and Zeng, X., 2016. Next-generation sequencing of mixed genomic DNA allows efficient assembly of rearranged mitochondrial genomes in Amolops chunganensis and Quasipaa boulengeri. Peer J., 4: e2786. https:// doi.org/10.7717/peerj.2786

Zhang, H.B., Li, Y.M., Wu, X.Y., Xue, H., Yan, P. and Wu, X.B., 2015. The complete mitochondrial genome of Paradoxornis webbianus (Passeriformes, Muscicapidae). Mitochond. DNA., 26: 879-880. https://doi.org/10.3109/19401736.2013.861440

Zhang, J.F., Nie, L.W., Wang, Y. and Hu, L.L., 2009. The complete mitochondrial genome of the largeheaded frog, Limnonectes bannaensis (Amphibia: Anura), and a novel gene organization in the vertebrate mtDNA. Gene, 442: 119-127. https:// doi.org/10.1016/j.gene.2009.04.018

Zhang, J.Y., Zhang, L.P., Yu, D.N., Storey, K.B. and Zheng, R.Q., 2018. Complete mitochondrial genomes of Nanorana taihangnica and $N$. yunnanensis (Anura: Dicroglossidae) with novel gene arrangements and phylogenetic relationship of Dicroglossidae. BMC Evol. Biol., 18: 26. https:// doi.org/10.1186/s12862-018-1140-2

Zhang, P., Liang, D., Mao, R.L., Hillis, D.M., Wake, D.B. and Cannatella, D.C., 2013. Efficient sequencing of anuran mtDNAs and a mitogenomic exploration of the phylogeny and evolution of frogs. Mol. Biol. Evol., 30: 1899-1915. https://doi. org $/ 10.1093 / \mathrm{molbev} / \mathrm{mst} 091$

Zhang, P., Zhou, H., Liang, D., Liu, Y.F., Chen, Y.Q. and $\mathrm{Qu}, \mathrm{L} . \mathrm{H} ., 2005$. The complete mitochondrial genome of a tree frog, Polypedates megacephalus (Amphibia: Anura: Rhacophoridae) and a novel gene organization in living amphibians. Gene, 346: 133-143. https://doi.org/10.1016/j. gene.2004.10.012 